\title{
Public primary oral health care: a bioethical reflection
}

\section{Cuidados em saúde bucal na Atenção Primária: uma reflexão bioética}

\begin{abstract}
In Brazil, a reduction in the prevalence of tooth decay has been observed recently. However, the distribution pattern of oral diseases still reflects widespread inequality in the access to public preventive and dental care. The oral health status of certain populations highlights the differences in the availability, accessibility and acceptability of education and oral health care. In this context, bioethics can be used as a concrete tool for the discussion, improvement and consolidation of citizenship, human rights and social justice. The purpose of this review is to reflect on Brazilian public primary oral health care from a bioethical standpoint. To do so, it is necessary to start with an analysis of the role of bioethics in public health in Brazil and to approach some of the ethical issues surrounding dental care in the Brazilian public health system.
\end{abstract}

Key words: Bioethics, primary health, oral health, dental assistance

\section{Resumo}

Embora nos últimos anos tenha se observado uma redução na prevalência de cárie dental no Brasil, o padrão de distribuição das doenças bucais ainda reflete a desigualdade no acesso aos cuidados preventivos e à assistência odontológica em todo o país. $\bigcirc$ nível de saúde bucal de uma população evidencia as diferenças na disponibilidade, acesso e aceitabilidade da educação e cuidados odontológicos. A bioética tem se colocado atualmente, como um instrumento concreto para discussão, aperfeiçoamento e consolidação da cidadania, dos direitos humanos e da justiça social. A proposta desta revisão bibliográfica é refletir, à luz da Bioética, sobre assistência à saúde bucal ofertada na Atenção Primária do Sistema Único de Saúde (SUS). Para isso, faz-se necessário partir da análise do papel da bioética no cenário atual da saúde pública no Brasil para então, buscar uma aproximação às questões éticas que permeiam a assistência odontológica no Sistema Único de Saúde.

Palavras-chave: Atenção Primária à saúde; saúde bucal; bioética, assistência odontológica

\section{Luciara Leão Viana Fonseca a,b Joaquim Antônio César Mota a Patricia Furtado Gonçalves a,b}

\begin{abstract}
- Programa de Pós Graduação em Ciências da Saúde, área de concentração Saúde da Criança e do Adolescente, Universidade Federal de Minas Gerais (UFMG), Belo Horizonte, MG, Brasil

b Departamento de Odontologia, Universidade Federal dos Vales do Jequitinhonha e Mucuri (UFVJM), Diamantina, MG, Brasil
\end{abstract}

\author{
Correspondence: \\ Luciara Leão Viana Fonseca \\ Rua Teófilo Otoni, 54. Centro \\ Diamantina, $M G$ - Brasil \\ 39100-000 \\ E-mail: luciaraleao@hotmail.com
}

Conflict of Interest Statement: The authors state that there are no financial and personal conflicts of interest that could have inappropriately influenced their work.

Copyright: (C) 2011 Fonseca et al.; licensee EDIPUCRS. This is an Open Access article distributed under the terms of the Creative Commons AttributionNoncommercial-No Derivative Works 3.0 Unported License. 


\section{Introduction}

The establishment of the Brazilian Health System (SUS) in the 1988 Constitution represented a break with the paradigm of public dental services, which had been previously offered mainly through school systems and free health services (1). The subsequent incorporation of dentistry into the Family Health Strategy (ESF) in December 2000 aimed to expand access to health promotion and improve oral disease prevention and treatment with subsequent improvement in epidemiological indicators (2). It also enabled the adoption of a more proactive attitude to oral health that involved the direct action of community dental teams through the implementation of epidemiological surveys, preventive and health education activities, and the execution of services aimed at groups with particular needs. Under the purview of the Brazilian dental program "Brasil Sorridente" (Smiling Brazil), Dental Specialty Centers (CEOs) increased the supply of specialized clinical care to the population and featured an innovative model of public oral health with potential for extended access and a greater range of services (3).

Until the early 1990 s, bioethics was restricted to biomedical health. However, bioethics has expanded to include aspects of biotechnology and social issues such as health and the environment (4). Since its establishment, bioethics has been redesigned and updated many times due to the difficulty of defining a topic with a constantly changing theme that varies according to the social contexts in which it is developed (5). On a conceptual basis, the bioethical principles proposed by Beauchamp and Childress, which are based on the four essential tenets of autonomy, beneficence, non-malfeasance and justice, are the most widespread.

With its unique process of evolution, bioethics has become a concrete tool for the discussion, improvement and consolidation of citizenship, human rights and social justice (6). In this context, this article reflects on the oral health situation in the Brazilian Primary Health Care System (SUS). Therefore, it is necessary to begin with an analysis of the current role of bioethics in Brazilian public health and to approach the issue through an examination of the practice of oral health in the SUS.

\section{Bioethics and Public Health}

Bioethics is both an academic discipline and a cultural movement. It is the result of the impact of the sociopolitical, cultural and techno-scientific developments that occurred in the mid-twentieth century. In public health, bioethics offers a multidisciplinary and interdisciplinary approach that views humans in their entirety. It aims to humanize the actions of health services and ensure the dignity and human rights of citizens and the users of these services (7).

Some authors $(8,9)$ consider the instruments that are offered by general bioethics insufficient for the analysis of the ethical issues of public health; they highlight the significant differences between health practices and clinical hospital scenarios. These differences typically refer to the levels of activities and services that are offered in both environments, the autonomy of users and the diversity of the proposed targets for professionals. These activities and services are directed toward comprehensive attention in primary care and are more focused and immediate in the clinical setting. The most frequent encounters between professionals and patients in primary care units usually occur in less urgent situations, which makes the conflicts more subtle, and they often go unnoticed. Therefore, it is necessary for bioethics to take a deeper look at the ethical conflicts of public health and consider the peculiarities of the scenario in which they occur and the broad social and economic discrepancies that highlight the vulnerability of users.

In Latin American countries, it is essential that this discussion be embedded in the operation of public health systems and include the following factors: a discussion of the social responsibility of the state, a definition of priorities regarding the allocation and distribution of resources, a discussion of systems management, the organized involvement of the population throughout the process, the preparation of appropriate human resources, a review and an update of codes of ethics for different professional groups and the necessary and profound changes in university curricula (10).

Two important concepts have been frequently used by Latin American researchers in bioethics because they reflect existent conditions in the region: the bioethics of emerging situations and the bioethics of persistent situations. The first condition treats questions that have arisen with recent biotechnological and scientific developments, including the human genome project and issues related to genetic engineering, the donation and transplantation of human tissues and organs, health reproduction, cloning, bio-security, and scientific research that utilizes humans (11).

Bioethics of persistent situations addresses issues that persist despite the socio-economic and technological development of a society, including social exclusion, discrimination in all forms, equity, universality and allocation themes, the control and distribution of economic resources in health, human rights, democracy in general and its repercussion in people's health and way of life, abortion and euthanasia (11).

According to Porto and Garrafa (12), bioethics of socalled peripheral countries should be concerned mainly with persistent situations and should look ahead, beginning in Latin America, to a discussion of strong interventionist bioethics. Therefore, intervention bioethics is a proposal under construction that includes a constant and many-sided discussion. Bioethics generates dynamic responses to an intense transformation of existing reality (13). It advocates a prioritization of policies and decision-making, among other issues, that favors the greatest number of people and the longest time period possible, and it urges the re-examination of certain dilemmas, such as autonomy versus justice/equity, individual benefit versus collective benefits, individualism versus solidarity, participation versus omission, and 
temporary changes versus permanent transformation (12). Its purpose is to legitimize the discussion of bioethics from a broad perspective, which involves the social production of disease and the effect of social inequality in practice and health services. It is differentiated from the idea of health as a quality of life and is expanding toward the recognition of social context as a legitimate field of study and intervention (14).

Another important tool in the bioethics' critical review of public policy is the principle of protection. According to Pontes and Schramm (15), in any civilized and democratic society, the state assumes the role of protecting all citizens in its territory because they do not have the objective and subjective means to protect themselves against certain risks and threats to their personal integrity (vulnerability). Therefore, protection can be understood as a safeguard of essential needs; protection should ensure that moral and legitimate requirements are met. From a health perspective, protection bioethics considers the right to health care and the equality of treatment as the main objects of study and focuses on devices that are capable of ensuring these rights (16).

Given the role of bioethics in public health discussions, it becomes evident that bioethics and public health have many points of convergence because both are concerned with issues of human rights, citizenship, social movements and public policy.

\section{Epidemiological Picture of Oral Health in Brazil}

In 2004, the Ministry of Health released data from the latest and largest epidemiological survey on the oral health status of the Brazilian population in recent years. According to these data, although a reduction in the prevalence of tooth decay was observed, the distribution pattern of oral diseases remained reflective of the inequality in the access to preventive and dental care across the country. The results revealed a troubling situation in oral health; the proportion of children with at least one primary tooth with a cavity increased from approximately $27 \%$ in children aged 18 to 36 months to almost $60 \%$ in five years. The average of primary teeth with cavities increased from one tooth in children up to 3 years to nearly three teeth in children 5 years of age (17).

Almost $70 \%$ of Brazilian 12-year-olds and about $90 \%$ of adolescents between 15 and 19 years of age had at least one permanent tooth with tooth decay. There was a growing trend in this prevalence by age, which is a common phenomenon considering the cumulative nature of dental caries. Large regional differences were also perceived at all ages. The lowest percentages of cavity-free children and adolescents and the highest average of treatment needs were observed more often in the North and Northeast compared to the South and Southeast (18).

The prevalence of caries in adults is progressive and increased from 20.1 teeth, on average, in patients aged 35 to 44 years to 27.8 in the $65-74$ age range. It is noteworthy that the missing component is responsible for approximately
$66 \%$ of the CPOD index (the mean number of teeth that are decayed, missing and restored) in the group of 35- to 44year-olds and nearly $93 \%$ in the group from 65 to 74 years of age. Cavities and missing teeth among adults and the elderly are profoundly elevated. Severe tooth loss remains a serious problem in Brazil, especially among the elderly, but among children and adolescents, the main problems are untreated decay, which reflects the lack of dental care (17).

Early tooth loss is also serious. The need for prostheses emerges in adolescence, from 15 to 19 years of age. Municipalities with low socioeconomic status are associated with higher rates of tooth extraction (18). An analysis by population size reveals that the most difficult conditions are localized in counties with smaller populations, especially counties with less than 10,000 people in which children and adolescents have a greater prevalence of caries and a higher mean of teeth with untreated cavities. Furthermore, this situation is generally repeated among adults and the elderly in cities with fewer than 50,000 inhabitants, which have a lower average of healthy teeth and a higher average of lost teeth (17). Regarding the prevalence of periodontal disease, approximately $10 \%$ of Brazilian adults present periodontal pockets in one or more regions of the mouth (17).

Disparities related to access to services were also identified in the national survey; approximately $14 \%$ of Brazilian adolescents reported never having visited the dentist. Regional inequalities are striking; although less than $6 \%$ of adolescents in the Southern Region had never visited the dentist, this percentage reached almost $22 \%$ in the Northeast Region (17). In the urban population, $10 \%$ of people had never consulted with a dentist, and in the rural population, this rate increased to $20 \%$ (19). One of the main reasons for seeking a dentist is the experience of dental pain (17).

It is possible that many of the noted differences are due to the model of care in each geographic area. Differences include the impact of broader policy measures, e.g., fluoridated water and toothpaste, and more specific measures related to the access and use of oral health care, such as a lack of human resources and staff (17).

\section{Bioethical Aspects of Care in Public Oral Health}

\section{Social inequities and access to oral health}

In general, the current disparities in the epidemiological picture of oral health reflect the differences in socioeconomic development between regions. Inequalities affect oral health in the same manner that they affect a wide range of health issues. Fundamentally, determinants of oral health are the same for general health and may not be strictly interpreted as a lack of dentists, lack of health care or a poor professional education model. However, the availability of dental care and health promotion affect the level of oral health, especially when prevention programs are offered. Therefore, the level of oral health reflects differences in the availability, accessibility and acceptability of oral health care and education (20). 
Socio-economic inequality is the most prominent characteristic of the Brazilian context, with severe consequences for health, especially oral health (2). In turn, inequality in access to dental care has sparked a broad bioethical debate because such inequality has been observed in several countries and it is often characterized by the fact that individuals with lower socioeconomic status have less access to oral health services $(21,22)$.

In Brazil, this situation is evidenced in data from the National Household Sample Survey (PNAD) that was conducted by IBGE in 2008 in which income inequality was especially pronounced among the elderly. In this population group, the differences in this indicator between the richest and the poorest reached more than $200 \%$ (23).

In addition, there was a linear relationship between oral health status and social position among adolescents in the states of São Paulo and Rio Grande do Sul (24). However, the linearity in family income was extended to a threshold above which an increase in income was accompanied by an improvement in oral health. This result indicates the likely influence of factors other than income.

Public health services constitute the main resource for the majority of the Brazilian population, especially for women of lower economic status, as evidenced by the results of PNAD in 2008 (23). The Health Center services were mainly referred to by $56.8 \%$ of the population as regularuse services, and a more frequent regular use was reported as monthly household income decreased. Conversely, as income increased, private offices and clinics were mentioned most often as the health services that were regular used (19).

Barros and Bertoldi (25) assessed the magnitude of the absence of public dental care and showed that SUS was responsible for $52 \%$ of general health treatments but only $24 \%$ of dental treatments. However, the results of the PNAD (2008) indicate that there was an increase in the access to dental care in more developed regions, although the geographical disparities remained large (23).

Recent studies have shown an increase in the availability of health professionals. According to Antunes and Narvai (3), over one-third (37.1\%) of dentists that were qualified by the Brazilian Federal Dental Council worked for the public service in 2008. Moreover, the proportion of dentists that were contracted by the SUS was highest in the North and Northeast regions, which indicates the effort to provide greater public dental care in regions where it is most needed.

Access to oral health is not restricted to dental treatment; it is also expressed in the access to preventive measures against oral diseases. Among these preventive measures, water fluoridation is recognized as a beneficial collective action because of its guaranteed effectiveness and large area of coverage. However, available data indicate that this measure is largely uneven in the country because it remains inadequate in the North and Northeast. In terms of public policy, the great inequality in the implementation of fluoridation originates at the national level. Its expansion has been so slow that, in the 21 st century, more than half of Brazilian municipalities have not adopted the measure. Therefore, adjustments in the management of public health policy are clearly needed (3).

The philosophy and organization of the health system and health education are also determinants of oral health (20). Therefore, when public health interventions are made without strategic planning that allows for the universalization of benefits or direct additional resources to more needy groups, they exert the undesirable effect of increasing inequalities in health. These inequalities are unjust, unnecessary and avoidable and are properly recognized as "inequities" (3). From the collective point of view, the bioethical principle of justice concerns equal access to health services for all people, the distribution of resources and the criteria to fairly resolve these issues (26).

Egalitarianism, which states that all persons are of inherent worth and should have their health needs met, is the basis of many of the current public health systems, including the SUS. Considering that each individual is a being with needs, the maximum guideline is to attend to each person according to his or her needs. However, due to cost pressures from various factors, including aging populations, the incessant increase of expensive technologies, changes in epidemiology and the emergence of new diseases and health problems, these universal systems undergo changes and reforms that require broad ethical reflection on the prioritization and limitations of the distribution of health resources (17).

\section{Financial resources}

In this regard, the major problems that are faced by the SUS are the result of the poor conditions of life (which have a major impact on levels of health) and budgetary and management difficulties that have marked the public administration (28). The provision of oral health care remains hampered by factors related to the financing of these activities and services, such as the difficulty in establishing a specific budget for oral health, the lack of financial resources and a delay in their transference (29). Therefore, these scenarios create constraints for access to oral health services, suffer from limitations in the nature of their actions and demonstrate the harsh reality of severe tooth loss, which is caused by the lack of a prosthesis, root canal treatment, periodontal treatment, and a lack of attention to the moderately complex needs in dentistry (30).

Socio-demographic factors, including sex, age, income and education, remain the main predictors of access to oral health services in certain places, but there is no difference in the access to oral health services in areas that are covered or not covered by ESF (31). However, there has been great progress in the investment in oral health care in recent years. The funding of these actions involved an annual federal investment increase from 56.5 million reais in 2003 to 427 million reais in 2005 and reached approximately 600 million reais in 2008. From 2003 to 2008, the Brazilian government invested approximately 2.4 billion reais in oral health care (3). 
Professional Training - Ethics in Education

Another important question to consider is Brazilian professional training, which is inappropriate for the desired profile of the Public Health System. The professional training that is offered by educational institutions is far from adequate in meeting the health needs of the population, and this deficiency has a direct influence on the quality and effectiveness of the health system $(32,33)$.

The lack of reflection by university leaders in everyday teaching and practice shows a degree of indifference regarding social injustice. They do not see the clear social and ethical responsibilities of the academy and have forgotten the transformative dimension of the university. They focus only on a certain level of responsibility and technical commitment. This focus makes the need for the integration of education and service clear and should guide the process of ethical reflection on the role of universities and their contribution to the construction/reconstruction of the practice (33).

When reviewing the importance of the role of ethics in the training of health professionals, Schuh and Albuquerque (34) showed the need for the transmission of humanistic values at the university level. Admission to college begins the process of professional socialization when the incorporation of professional morality is determined by the adoption of models and the internalization of the behaviors and attitudes that are accepted among peers. The authors show that, in the health field, the teaching of ethics lags behind the needs of society. There is more interest in techniques than ethics, and there are too few specialists in this field (34).

The teaching of bioethics in graduate courses constitutes a framework that allows for reflection and a critical view of the world by focusing attention on the social, cultural and economic problems of a population. It should stimulate the social commitment to improving people's quality of life, especially in the sphere of professional actions (35).

Francesconi and Goldim (36) expressed concern that students and trainees from different specialties do not receive the same level of education in the scientific, technical and ethical fields. They assert that the 21 st century needs a new paradigm in which health professionals receive the same proficiency in all three areas simultaneously and have the ability to exercise their expertise in different social realities. The people who are responsible for education in the health field should endeavor to put the concept of the indivisibility of the three compartments into practice, which would result in more complete clinical practice.

\section{Model of professional practice}

The overall goals of oral health care to be implemented in the municipalities remain unclear, although some documents point to priorities within the PSF and the opening of specialized dental centers for the treatment of more complex dental problems. (37).

The design of a practice that is focused on the dental care of the individual patient and performed exclusively by an individual in a restricted surgical clinical environment has prevailed in the private sector and exerts a powerful influence on public services (28). The similarity of professional practices that are performed in public and private environments shows that public services often reproduce these activities mechanically and uncritically, out of touch with the needs of the patient $(28,38)$.

The approach to issues other than dental caries in the public system and a discussion of the importance of the interaction of oral health with general health is rare in the discourse and practice of professionals. The development of health promotion activities at the collective level occurs mostly in the area of health care or schools with little use of other social spaces in the community. There is little regularity in the implementation of these actions, except in certain groups, such as pregnant women or children. Dentists do not use risk criteria to establish the direction of activities, and most dentists have not reported the use of assessment tools to evaluate the impact of their actions (38).

Health education as a social practice aimed at the collective and other preventive measures, such as oral hygiene, fluoridation and non-carcinogenic diet, represent important opportunities to expand operations in the practice of oral health promotion in public spaces. However, they must be based on educational programs to be successful (39).

As a member of a multidisciplinary team, the dentist should not forget the importance of a humane, personalized and bioethically correct approach (40). All health professionals have a duty to take care of the people under their care (41). This is not a juridical duty but a human one, the duty of a fellow citizen who listens, comforts and respects the dignity of the patient.

In addition, any proposed health care interventions should take the reality of each social context into account to understand the individual, the citizen and the social networks that have been built. Therefore, it will be possible to define the needs, problems and collective processes of the transformation of the life model necessary to achieve oral health. These interventions are positive and consider the social spaces and their movements, with an emphasis on the enhancement of collective oral health quality. This idea constitutes a major challenge because it involves a transformation of the organizational form of oral health practices from a paternalistic model of care to one that emphasizes co-responsibility and is participatory and democratic (42).

Human dignity is the core of fundamental human rights, and its recognition as the foundation of the state, which is guaranteed by the Brazilian constitution, shows that the state exists as a function of the individual and not vice versa. Even sick people maintain their fundamental rights and citizenship. In fact, illness attaches greater importance to some of these fundamental rights, which are recognized as "user rights" in letters and statements that serve to guide actions toward the humanization of assistance $(41,43)$. 


\section{Final Considerations}

In the light of bioethics, we must consider the epidemiological situation of oral health in Brazil. There are several aspects that directly influence the population's access to public dental services and actions that contribute to inequities in oral health. These aspects are questions of ethical content and can be examined from ethical standpoints, especially protection and intervention bioethics.

From the point of view of protection bioethics, health authorities are responsible for the reasonable and effective well-being of the population by ensuring access to health services and other health programs. The responsibility for the implementation of health policies lies with public officials who must take the necessary actions to meet the health needs of the population and protect them from vulnerabilities and genuine threats to their health, despite the difficulties that this entails. Protective responsibility necessarily implies the control of the outcome of adopted policies and the evaluation of the performance of institutions and their employees (44).

The principle of protection should also be relied on to prioritize or focus the investments of the state, including the study of the destination, allocation, distribution and control of financial resources to disadvantages citizens (45). However, the bioethical principles of protection and responsibility are not restricted to the state and its representatives. They must be embraced by each dental professional in his or her practice. These principles must be taken into account when professionals work in human health care, which is neither limited nor exhausted in clinical care, but rather expands, knows, understands, and establishes responsibility links with the community.

Intervention bioethics presupposes the search for completeness, justice and social inclusion as essential elements for effective citizenship. Health is synonymous with citizenship (46). The principle of justice is applied when health professionals use the resources of epidemiology and social risk criteria to detect vulnerable individuals and facilitate their access to oral health care.

The integration of actions in dentistry become reality when oral health teams engage more deeply in the promotion of health, which increases their spaces of social action. Bioethics must be taught effectively and practiced in graduate courses. It is necessary that bioethical values, such as dignity, human rights, respect for autonomy and vulnerability, are discussed and incorporated into academic practice so that they can be incorporated into the operation of the SUS. Therefore, a discussion of the organization of public dental services for the true accomplishment of the model that was proposed by the National Oral Health Policy should include relevant aspects of bioethical awareness by oral health professionals and the development of attitudes that go beyond the limits of mere clinical assistance.

References 1. Narvai PC. Odontologia e Saúde Bucal Coletiva. São Paulo: Hucitec;1994.

2. Baldani MH, de Almeida ES, Antunes JL. Eqüidade e provisão de serviços públicos odontológicos no estado do Paraná. Rev Saúde Pública 2009;43:46-54.

3. Antunes JL, Narvai PC. Políticas de saúde bucal no Brasil e seu impacto sobre as desigualdades em saúde. Rev Saúde Pública 2010;44:360-5.

4. Corrêa AP, Garrafa V. Conselho Nacional de Bioética A Iniciativa Brasileira. Rev Bras Bioet 2005;1:401-16.

5. Kottow M. Bioética: especialidade acadêmica ou movimento social. Rev Bras Bioet 2007:3:330-45

6. Garrafa V, Azambuja LE. Epistemologia de la bioética - enfoque latino-americano. Rev Bras Bioet 2007;3:346-61

7. Fortes PA, Zoboli EL. Bioética e Saúde Pública. $2^{a}$ ed. São Paulo:Edições Loyola; 2004.

8. Zoboli EL, Fortes PA. Bioética e atenção básica: um perfil dos problemas éticos vividos por enfermeiros e médicos do Programa Saúde da Família, São Paulo, Brasil. Cad Saúde Pública 2004;20:1690-9.

9. Schramm FR, Kottow M. Principios bioéticos en salud pública: limitaciones y propuestas. Cad. Saúde Pública 2001;17:949-56.

10. Garrafa V. Da bioética de princípios a uma bioética interventiva. Bioética [Online] 2005 [acesso 20 ago. 2010];13:124-34. Disponível em: http://www.portalmedico.org.br/ revista/biol 3v1/simposios/simposio09.htm.

11. Garrafa V. Introdução à Bioética. Rev Hosp Universitário UFMA 2005;6:9-13.

12. Garrafa V, Porto D. Bioética, Poder e injustiça: Por uma ética de intervenção. O Mundo da Saúde 2002;26:6-15

13. Cruz MR, Trindade ES. Bioética de Intervenção - uma proposta epistemológica e uma necessidade para sociedades com grupos sociais vulneráveis. Rev Bras Bioet 2006; 2:483-500.

14. Porto D, Garrafa V. Bioética de intervenção: considerações sobre a economia de mercado. Rev Bioet [internet]. 2009 set 14 [acessado em 15 set. 2010];13(1). Disponível em: http:// revistabioetica.cfm.org.br/index.php/revista_bioetica/article/view/96/91

15. Pontes CA, Schrammm FR. Bioética da proteção e papel do Estado: problemas morais no acesso desigual à água potável. Cad Saúde Pública 2004; 20:1319-27.

16. Schramm FR. Proteger os vulnerados e não intervir aonde não se deve. Rev Bras Bioet 2007:3:379-91. 
17. Brasil. Ministério da Saúde. Secretaria de Assistência à Saúde. Departamento de Atenção Básica. Coordenação Nacional de Saúde Bucal. Projeto SB Brasil 2003. Condições de saúde bucal da população brasileira 2002-2003. Resultados Principais. Ministério da Saúde: 2004. 51 p.

18. Fernandes $L S$, Peres MA. Associação entre atenção básica em saúde bucal e indicadores socioeconômicos municipais. Rev. Saúde Pública [periódico na Internet]. 2005 [acessado em 26 Abr 2010]; 39:930-6. Disponível em: http://www.scielo.br/scielo. php? script=sci arttext\&pid=S0034-89102005000600010\&lng=pt. doi: 10.1590/ S0034-89102005000600010

19. Brasil, Ministério da Saúde. IBGE, Ministério do planejamento, orçamento e gestão. PNAD. Acesso e utilização dos serviços de saúde. 2008. Rio de Janeiro, 2010.

20. Hobdell M, Sinkford J, Alexander C, Alexander D, Corbet E, Douglas C et al. Ethics, equity and global responsibilities in oral health and disease. Eur J Dent Educ 2002;6:167-78.

21. Evans CA. Eliminating oral health disparities: Ethics workshop reactor comments. J Dent Educ 2006;70:1180-3.

22. Dharamsi S. Building moral communities? First, do no harm. J Dent Educ 2006;70: 1235-40.

23. Viacava F. Acesso e uso dos serviços de saúde pelos brasileiros. Radis: Comunicação em Saúde 2010;96:12-19.

24. Celeste RK, Nadanovsky P, Ponce de Leon A. Associação entre procedimentos preventivos no serviço público de odontologia e a prevalência de cárie dentária.Rev Saúde Pública 2007;41: 830-8.

25. Barros AJD, Bertoldi AD. Desigualdades na utilização e no acesso a serviços odontológicos: uma avaliação em nível nacional. Cienc Saúde Colet 2002;7:709-17.

26. Ramos DL, editor. Bioética \& Ética Profissional. Rio de Janeiro: Guanabara Koogan; 2007.

27. Fortes P. Orientações bioéticas de justiça distributiva aplicada às ações e aos sistemas de saúde. Rev Bioet 2008;16:25-39.

28. Narvai PC. Saúde bucal coletiva: caminhos da odontologia sanitária à bucalidade. Rev Saúde Pública 2006;40:141-7.

29. Moimaz SA, Garbin CA, Garbin AJ, Ferreira NF, Gonçalves PE. Desafios e dificuldades do financiamento em saúde bucal: uma análise qualitativa. Rev Adm Publica 2008;42: $1121-35$.

30. Pires LA, Cerveira J. A Bioética na Odontologia. Stomatos 2003;9:7-12.

31. Rocha RA, Goes PS. Comparação do acesso aos serviços de saúde bucal em áreas cobertas e não cobertas pela Estratégia Saúde da Família em Campina Grande, Paraíba, Brasil. Cad Saude Publica 2008;24:2871-80.

32. Martins RJ, Moimaz SA, Garbin CA, Garbin AJ, Lima DC. Percepção dos Coordenadores de Saúde Bucal e Cirurgiões-Dentistas do Serviço Público sobre o Sistema Único de Saúde (SUS). Saúde Soc 2009;18:75-82.

33. Amorim KP, Germano RM, Avelino AN, Costa IC. Mutilações dentárias: os dilemas da prática na visão de docentes universitários. Rev Bioet 2009;17:109-21.

34. Schuh CM, Martins de Albuquerque I. A ética na formação dos profissionais da saúde: algumas reflexões. Rev Bioet 2009; 17:55-60.

35. Prado MM, Garrafa VA Bioética na formação em odontologia: importância para uma prática consciente e crítica. Comun Ciênc Saúde 2006;17:263-74.

36. Francesconi CF, Goldim CR. Bioética Clínica. In Clotet J, Feijó A, Oliveira MG. Bioética: uma visão panorâmica. Porto Alegre: EDIPUCRS, 2005.

37. Chaves SC, Vieira-da-Silva LM. Atenção à saúde bucal e a descentralização da saúde no Brasil: estudo de dois casos exemplares no Estado da Bahia. Cad Saúde Pública 2007; 23:1119-31

38. Almeida GC, Ferreira MA. Saúde bucal no contexto do Programa Saúde da Família: práticas de prevenção orientadas ao indivíduo e ao coletivo. Cad. Saúde Pública [periódico na Internet]. 2008 Set [acessado em 2010 Abr 22] ; 24(9): 2131-2140. Disponível em: http://www.scielo.br/scielo.php?script=sci_arttext\&pid=S0102$311 \times 2008000900019 \&$ lng $=\mathrm{pt}$

39. Pauleto AR, Pereira ML, Cyrino EG. Saúde bucal: uma revisão crítica sobre programações educativas para escolares. Ciênc Saúde Colet 2004; 9:121-30.

40. Jorge ES, Lucato MC, Dalmolin RA, Jorge MD. Humanização das relações assistenciais. In: Ramos DL, editor. Bioética \& Ética Profissional. Rio de Janeiro: Guanabara Koogan; 2007.

41. Nunes L. Usuários dos Serviços de Saúde e os seus direitos. Rev Bras Bioet 2006; 2: 201-19.

42. Cordón J. A construção de uma agenda para a saúde bucal coletiva. Cad Saúde Pública 1997;13:557-63.

43. Santos LR, Eidt OR. Os direitos do cidadão usuário do Sistema Único de Saúde: um enfoque da Bioética na Saúde Coletiva. Acta Paul Enferm 2004;17:347-53.

44. Schramm FR. A bioética da Proteção em Saúde Pública. "In": Fortes PAC, Zoboli ELCP, organizadores. Bioética e Saúde Pública. $2^{a}$ ed. São Paulo: Edições Loyola; 2004.

45. Arreguy EE, Schramm FR. Bioética do Sistema Único de Saúde/SUS: uma análise pela bioética da proteção. Rev Bras Cancerol 2005;51:117-23.

46. Gonçalves ER, Ramos FR, Garrafa V. O olhar da Bioética de Intervenção no trabalho do cirurgião-dentista do Programa Saúde da Família (PSF). Rev Bioet 2010;18:225-39. 